\title{
A developmental-specific factor binds to suppressor sites flanking the immunoglobulin heavy-chain enhancer
}

\author{
Richard H. Scheuermann ${ }^{1}$ and Una Chen \\ Basel Institute for Immunology, 4005 Basel, Switzerland
}

\begin{abstract}
We identified a novel nuclear protein, NF- $\mu$ NR, that binds to multiple sites flanking the immunoglobulin heavy-chain enhancer. The expression of NF- $\mu$ NR shows a unique developmental pattern; the activity is present in all cells representing early stages of B-cell development, but is absent from more mature cells that express a high level of immunoglobulin heavy chains. NF- $\mu$ NR also is present in most cell lines outside of the B-cell lineage (e.g., $\mathrm{T}$ cells, macrophages, and fibroblasts). The binding sites for NF- $\mu$ NR correlate very well with cisacting negative regulatory elements of the heavy-chain enhancer defined previously. Indeed, when the segments bound by NF- $\mu$ NR are deleted from the enhancer, it is now found to function as a positive transcription element in $T$ cells and macrophages. Taken together, these results suggest that NF- $\mu$ NR may function as a negative regulator of enhancer function. The observation that the segments bound by NF- $\mu$ NR correspond to the segments bound to the nuclear matrix suggests an intriguing model not only of how enhancers might function but also of how negative regulation might occur.
\end{abstract}

[Key Words: Enhancer regulation; DNA-binding protein; nuclear matrix attachment]

Received November 8, 1988; revised version accepted May 29, 1989.

Immunoglobulin gene expression represents a model system for understanding the mechanism of developmental-specific gene regulation. Expression of the immunoglobulin heavy-chain $(\mathrm{IgH})$ gene is regulated by a number of cis-acting elements that function at the level of RNA synthesis and stability, including promoter elements upstream of the transcription initiation site (Grosschedl and Baltimore 1985; Mason et al. 1985) sequences internal to the structural gene (Grosschedl and Baltimore 1985), and a transcriptional enhancer (Banerji et al. 1983; Gillies et al. 1983; Mercola et al. 1983; Neuberger 1983). The enhancer is an important component of the heavy-chain transcriptional unit because it acts not only to stimulate regulated transcription from the promoter, but also functions as a cell-type-specific regulator.

Enhancer elements, identified initially in association with viral genes (see Khoury and Gruss 1983), have been defined as cis-acting sequences that can act to stimulate transcription in an orientation-independent manner at relatively large distances from the promoter. The molecular mechanism by which enhancers can function in this position-independent manner remains obscure. In transfection experiments, a region within the immunoglobulin heavy-chain J-C intron also was found to function as an enhancer, however, in this case the enhancer demonstrated tissue specificity in that it increased the level of transcription of marker genes in B cells but not

${ }^{1}$ Corresponding author. in fibroblasts (Banerii et al. 1983; Gillies et al. 1983). Subsequently, enhancers have been found in association with a variety of cellular genes, many of which seem to function in a tissue-specific or inducible manner (Chandler et al. 1983; Walker et al. 1983; Gorman et al. 1985; Rossi and deCrombrugghe 1987). Thus, enhancer regulation appears to be an important aspect of developmental gene regulation.

A number of experiments suggest that the heavychain enhancer functions as a recognition site for tissuespecific trans-acting factors. In vivo footprint experiments demonstrated cell-type-specific protection of sequences within the enhancer (Church et al. 1985; Ephrussi et al. 1985). Enhancer-mediated transcription of a marker gene can be reduced by cotransfection of competitor enhancer DNA (Schöler and Gruss 1984; Mercola et al. 1985). In vitro transcription experiments also demonstrate the requirement of trans-acting factors for tissue-specific enhancer function (Schöler and Gruss 1985). Thus, enhancer function seems to be mediated by trans-acting factors that function in a tissue-specific manner. Several groups have reported the binding of factors to the heavy-chain enhancer in vitro. At least five different factors that bind to the 'core' enhancer / the PstI-EcoRI fragment) have been identified (Augereau and Chambon 1986; Schlokat et al. 1986; Sen and Baltimore 1986a; Singh et al. 1986; Peterson et al. 1986; Weinberger et al. 1986; Gerster et al. 1987). Factor binding also has been observed to regions that flank the enhancer core (Peterson et al. 1986). However, the im- 
portance of these factors to the tissue-specificity of the enhancer function has been difficult to demonstrate as the majority of these factors appear to be present ubiquitously, even in cells that do not support enhancer function.

Recently, evidence for the negative regulation of the heavy-chain enhancer has been presented (Kadesch et al. 1986; Wasylyk and Wasylyk 1986). Indeed, experiments using deletion mutants within the enhancer suggest that tissue specificity is, at least in part, mediated by sequences that flank the core enhancer and that act to repress enhancer function, that is, removal of these flanking sequences allows enhancer-mediated gene expression in fibroblasts (Imler et al. 1987).

To gain a better understanding of the complex mechanism of developmental-specific enhancer function, the interaction of nuclear factors with the DNA sequences around the immunoglobulin heavy-chain enhancer has been investigated. We report here the identification of a protein factor that binds to multiple sites flanking the heavy-chain core enhancer. This factor is not detected in cells that express the immunoglobulin heavy chain. In cells that express this factor, the heavy-chain enhancer is nonfunctional, but enhancer activity can be restored by the deletion of the nuclear factor binding sites. These results support the notion that the tissue specificity of the heavy-chain enhancer also is controlled by a negative-regulatory factor present in nonexpressing cells.

\section{Results}

Identification of a novel factor binding to enhancerflanking regions

To detect factors that might bind to DNA sequences in and around the immunoglobulin heavy-chain enhancer, mobility shift assays (Fried and Crothers 1981; Garner and Revzin 1981), and competition experiments were performed using restriction fragment probes within the $\mathrm{J}-\mathrm{C}$ intron as depicted in Figure 1. With this assay, the presence of a new band with altered mobility compared with the free fragment is indicative of a specific interaction between factors present in the nuclear extract and the purified DNA fragment. As has been reported pre- viously, three major retarded bands are evident when a DNA fragment containing the enhancer core was assayed (Fig. 2, lanes 7-9). The additional upper band seen with the core fragment probably is the result of contamination of $3^{\prime}$-En DNA in this fragment preparation as this band is not seen with other core fragment preparations. These three bands are present using nuclear extracts from the plasmacytoma 5558L (lane 7), the pre-B cell line 18.81 (lane 8), and the T cell line EL-4 (lane 9). In contrast, a different retarded band is seen when two different DNA fragments $3^{\prime}$ of the enhancer core or a fragment $5^{\prime}$ of the core are used with the same set of extracts (Fig. 2, lanes 1-3, 4-6, and 10-12). This binding factor is absent with the plasmacytoma extract (lanes 1,4 , and 10), abundant with the T-cell extract (lanes 3, 6, and 12), and present when an extract from the PD31 pre-B cell line is used (lane 13). The fact that the position of the retarded band and the cell type distribution are different from that seen with the enhancer core suggests that a distinct factor binds to these DNA segments.

The specificity of this interaction was assayed by competition experiments using labeled $5^{\prime}$-En and $5^{\prime}-\mathrm{S} \mu(\mathrm{b})$ fragments and a variety of cold DNA fragments as competitors (Fig. 3). Using the $5^{\prime}-\mathrm{S} \mu(\mathrm{b})$ fragment as a probe (Fig. 3A), little competition is observed with the addition of a fivefold excess of DNA from the enhancer core (lane 10), the $\gamma 2 \mathrm{~b}$ switch region (lanes 5-7), or with two other DNA fragments between the enhancer and $S \mu$ (lanes 4 and 8). Indeed, when these fragments are used as probes in a mobility shift assay, a similar retarded band is not seen (R.H. Scheuermann and U. Chen, unpubl.). On the other hand, both the $5^{\prime}-\mathrm{S} \mu(\mathrm{b})$ DNA (lane 3 ) and 3 '-En DNA (lane 9) are able to compete for binding to labeled $5^{\prime}-S \mu(b)$. These results demonstrate that the same factor interacts with these two DNA segments and that it is distinct from the factors that interact with the enhancer core. Similarly, the 3 '-En fragment competes effectively for binding to the labeled 5 '-En fragment (Fig. 3B, open circles). The results of these and other unpublished experiments can be summarized as follows: All three fragments are able to compete for the binding of the same nuclear factor, regardless of which fragment is used as the probe, however, the $3^{\prime}$-En and $5^{\prime}$-En frag-

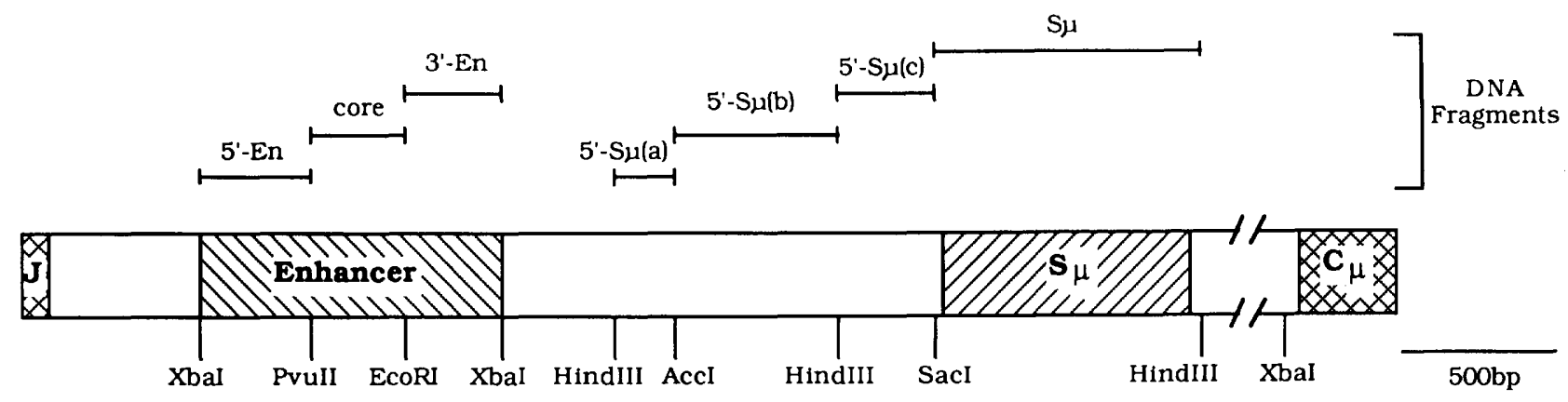

Figure 1. Organization of the mouse heavy-chain J-C intron. The pertinent restriction enzyme cleavage sites within the J-C intron are indicated, as determined by analysis of published sequences (GenBank, Genetics Sequence Data Bank Release 1986) and empirically. (Cross-hatched regions) Protein coding exons; (hatched enhancer region) the 1.0 -kb enhancer segment as defined by transfection analysis in B cells (Banerii et al. 1983; Gillies et al. 1983); (hatched $S_{\mu}$ region) the $\mu$ isotype-switch repeats; (open bars) intron sequences with unknown function. Relevant DNA fragments used in this study are indicated (see Methods). 


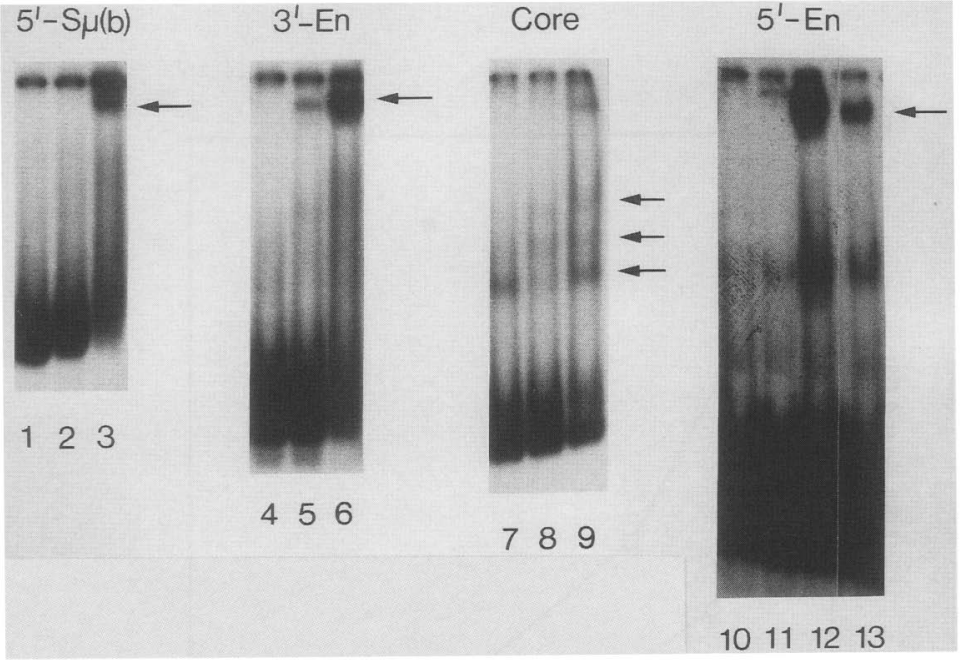

Figure 2. Nuclear factor binding to DNA segments within the heavy-chain J-C intron. Nuclear extracts 13 $\mu \mathrm{g})$ prepared from four different cell lines were incubated with ${ }^{32} \mathrm{P}$-end-labeled DNA fragments ( $2 \mathrm{ng}$ ) as indicated and analyzed for DNA binding by the mobility shift assay. (Lanes 1, 4, 7, and 10) J558L nuclear extracts; (lanes 2, 5, 8, and 11) 18.81 nuclear extract; (lanes 3, 6, 9, and 12) EL-4 nuclear extract; (lane 13) PD31 nuclear extract; (arrows) extract-dependent retarded DNA bands. ments are bound with a much higher affinity than the $5^{\prime}-\mathrm{S} \mu(\mathrm{b})$ fragment.

\section{Developmental regulation of the nuclear factor DNA. binding activity}

To determine whether the nuclear factor is specific to a particular cell type, nuclear extracts prepared from a variety of different cell lines were tested for their ability to bind these DNA fragments. Strong binding activity was observed with extracts from two pre-B cell lines PD31 and 230-37; three $T$ cell lines, EL-4, BW5147, and A32-26; the myeloma MOPC511; and the macrophage line P388D1 (Fig. 4A). Considerable binding also was observed with extracts from NIH-3T3 fibroblasts and the mammary carcinoma line C127. Little or no binding was observed with extracts from bacterial lipopolysaccharide (LPS)-stimulated spleen cells, the J558L plasmacytoma, pre-B-cell line 18.81, I29.48 with or without LPS stimulation, CTL-L cytotoxic T cell line, and WEHI-3 macrophage line.

Further analysis was performed with a series of extracts from cells that represent different stages within the B-cell lineage (Fig. 4B). Binding activity was present in early progenitor cell lines and in pre-B cells, which lacked $\mu$ protein expression (lanes $2-7$ ). The binding factor was not detected in all pre-B cells, lymphoid B cells, plasmacytomas, and hybridoma cell lines, all of which express heavy chains. Thus, the presence of this binding factor correlates well with the absence of heavychain expression, both within the B-cell lineage and with non-B cell lines. On the basis of the cell-type distribution and the functional analysis described below, we refer to this binding factor as NF- $\mu$ NR for Nuclear Factor $\mu$ Negative Regulator.

There are three exceptions to this general rule that require attention: the presence of NF- $\mu$ NR in MOPC511, the absence of this factor in WEHI-3, and its absence in CTL-L. MOPC511 originally was isolated as an immunoglobulin-secreting (IgA, ) myeloma (Hood et al. 1973); however, it was found subsequently to contain rear- ranged T-cell receptor genes (Traunecker et al. 1986). In addition, the particular isolate used in this study no longer expresses IgA as judged by immunofluorescence (L. Forni and R. Scheuermann, unpubl.). Thus, the absence of heavy-chain expression may in part be a result of the presence of NF- $\mu$ NR in these cells. The absence of NF- $\mu$ NR in WEHI- 3 and CTL-L suggests that the heavychain enhancer could be functional. However, we have been unable to detect any $\mathrm{C} \mu$ transcripts in these lines using nuclear run-on analysis (R. Scheuermann and $S$. Bauer, unpubl.). This observation may reflect the requirement for positive factors that might be absent in these lines. In support of this idea, we have been unable to detect binding to enhancer core fragments using nuclear extracts from WEHI-3 (R.H. Scheuermann and U. Chen, unpubl.).

\section{Localization of the binding motifs by DNase footprinting}

The binding sites within the enhancer-flanking segments were localized by examining the ability of a partially purified extract to protect the DNA from DNase I treatment. The nuclear factor present in a heparinagarose column fraction $\left(\mathrm{F}_{\mathrm{II}}\right)$ was found to protect two regions (Prot. 1 and 2) within the $5^{\prime}$-En fragment (Fig. $5 \mathrm{~A}$ ), separated by $\sim 87 \mathrm{bp}$. The nuclear factor also was found to protect two regions within the 3 '-En fragment (Prot. 3 and 4), separated by a shorter spacer region of $\sim 18 \mathrm{bp}$. The four protected regions were compared with one another using a matrix program to find regions of homology. In Figure 5B, the protected regions are listed to align the homologous segments and a consensus sequence is given. A stretch of nine consecutive base pairs was found in which at least three of the four protected regions match the consensus. This stretch exhibits dyad symmetry around the internal AT nucleotides. Interestingly, the protected regions are extremely AT rich $(\sim 80 \% \mathrm{~A}+\mathrm{T})$, with the majority of the Gs and Cs at the fringes of the protected regions. In support of the importance of the $\mathrm{A}$ and $\mathrm{T}$ nucleotides, we have been un- 

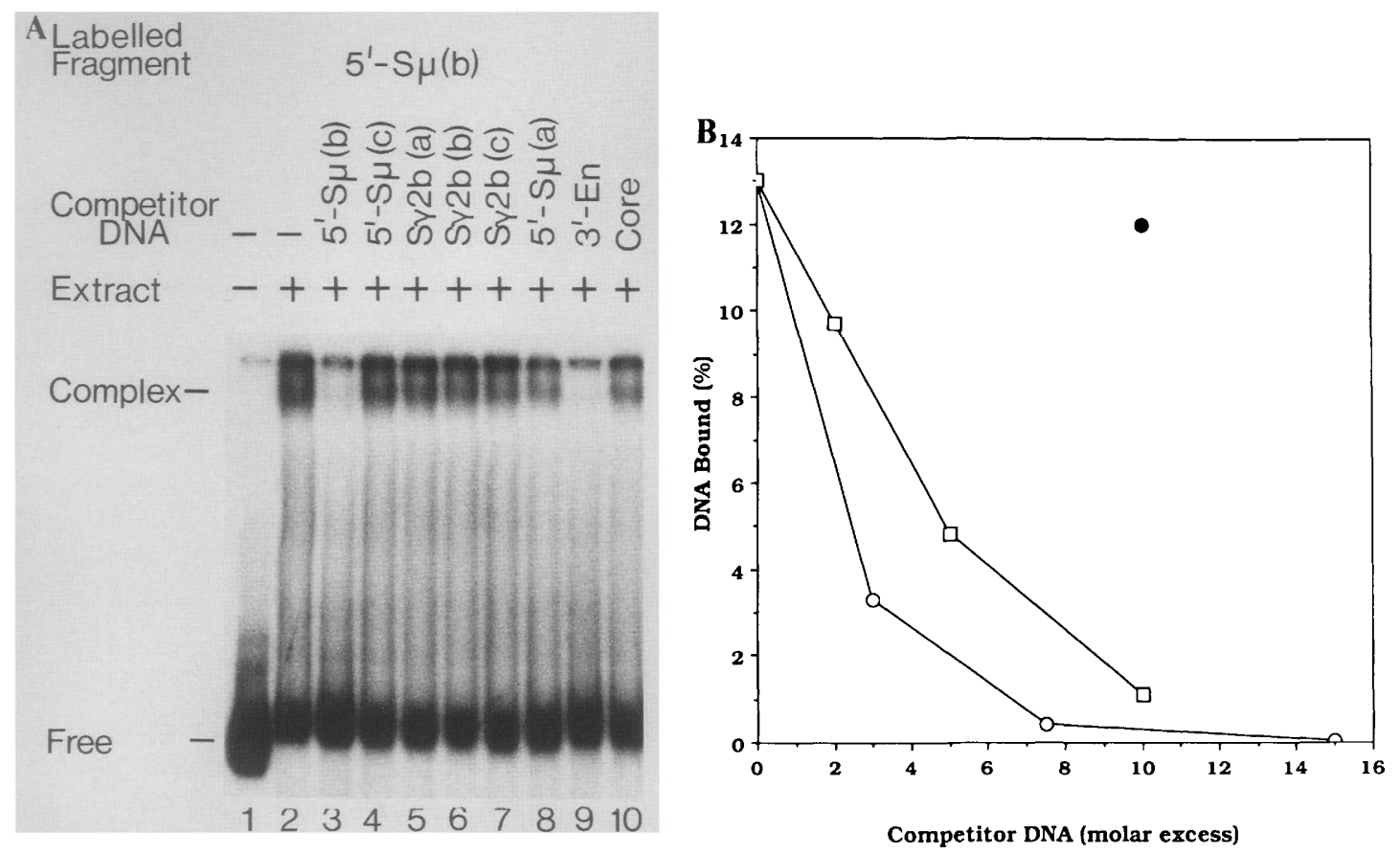

Figure 3. Specificity of factor binding to $5^{\prime}-\mathrm{S} \mu(\mathrm{b})$ and $3^{\prime}$-En fragments. Nuclear extracts were added to reaction mixes containing a 32P-labeled DNA fragment and a variety of different cold competitor DNAs, and the mobility shift assay performed as in Fig. 2. $(A)$ Competition experiment to determine whether the same factor interacts with both fragments. Reaction mixes contained $1.5 \mu \mathrm{g}$ of EL-4 nuclear extract, $8 \mathrm{ng}$ of ${ }^{32} \mathrm{P}$-labeled $5^{\prime}-\mathrm{S} \mu(\mathrm{b})$, and a fivefold molar excess (nucleotides) of cold competitor DNA as indicated. $(B)$ Competition experiment to measure relative binding affinities using labeled $5^{\prime}-\mathrm{En}$. Reaction mixes contained $0.16 \mu \mathrm{g}$ of $\mathrm{F}_{\mathrm{mI}}$ fraction,

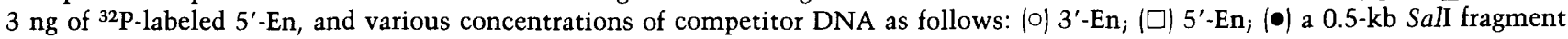
from phage $\lambda$ DNA. After autoradiography, the percent of complexed DNA was determined by scanning laser densitometry.

able to demonstrate binding interference of methyl-G using the $3^{\prime}$-En fragment (R.H. Scheuermann and $U$. Chen, unpubl.).

NF- $\mu$ NR was purified further on the basis of its ability to bind the Protection 2 region with an oligonucleotide affinity column (Kadonaga and Tiian 1986). The fraction of protein that bound and eluted from this column $\left(\mathrm{F}_{\mathrm{IV}}\right)$ showed considerable purification on the basis of the complexity of the silver staining pattern following SDS-polyacrylamide gel electrophoresis (Fig. 5C) and on the increase in specific activity. This purified fraction was tested for its ability to protect the two DNA fragments from DNase digestion (Fig. 5A); again, even this more purified fraction was found to protect all four regions. Because this purification step is based only on binding to the Protection 2 region, these data support the idea that the same factor is binding to all four sites. The observation that this nuclear factor binds to two sites within each fragment separated by short spacer regions suggests that it may function as a multimer of homologous units or as a single subunit with multiple binding sites.

\section{Functional analysis of NF- $\mu$ NR binding}

To test the hypothesis that the NF- $\mu$ NR binding sites are involved in tissue-specific regulation, the enhancing activity of the complete IgH enhancer, which contains the NF- $\mu$ NR binding sites, was compared with the enhancer 'core' in a variety of cell lines using a transient transfection and chloroamphenicol acetyltransferase (CAT) expression assay (Fig. 6A). The complete enhancer was found to be functional in the B cell line $5558 \mathrm{~L}$ and nonfunctional in the macrophage line P388D1 and the T cell line BW5147 in support of its tissue specificity. In contrast, the enhancer core was functional in all of these cell lines; indeed, in BW5147 it gave enhancing activity comparable to that provided by the SV40 enhancer. Thus, the ability of the complete IgH enhancer to function correlates well with the presence or absence of NF$\mu N R$ in these cell lines; deletion of the NF- $\mu$ NR binding sites allows the enhancer core to function in all of these cell lines. The ability of the core enhancer to function in the non-B cell lines cannot simply be a result of a 'distance effect' (deletion of the flanking segments would bring the core closer to the promoter) as both types of enhancer constructs give similar activities in the B cell line. It should be noted that because the enhancer containing fragments are placed directly upstream of the promoter the effects seen may not reflect authentic 'enhancer' function; this would require demonstration of position and orientation independence. However, it is clear from these results that the enhancer core is required to activate transcription in this system and that it can function in either orientation.

As a direct test of whether the NF- $\mu$ NR binding sites 

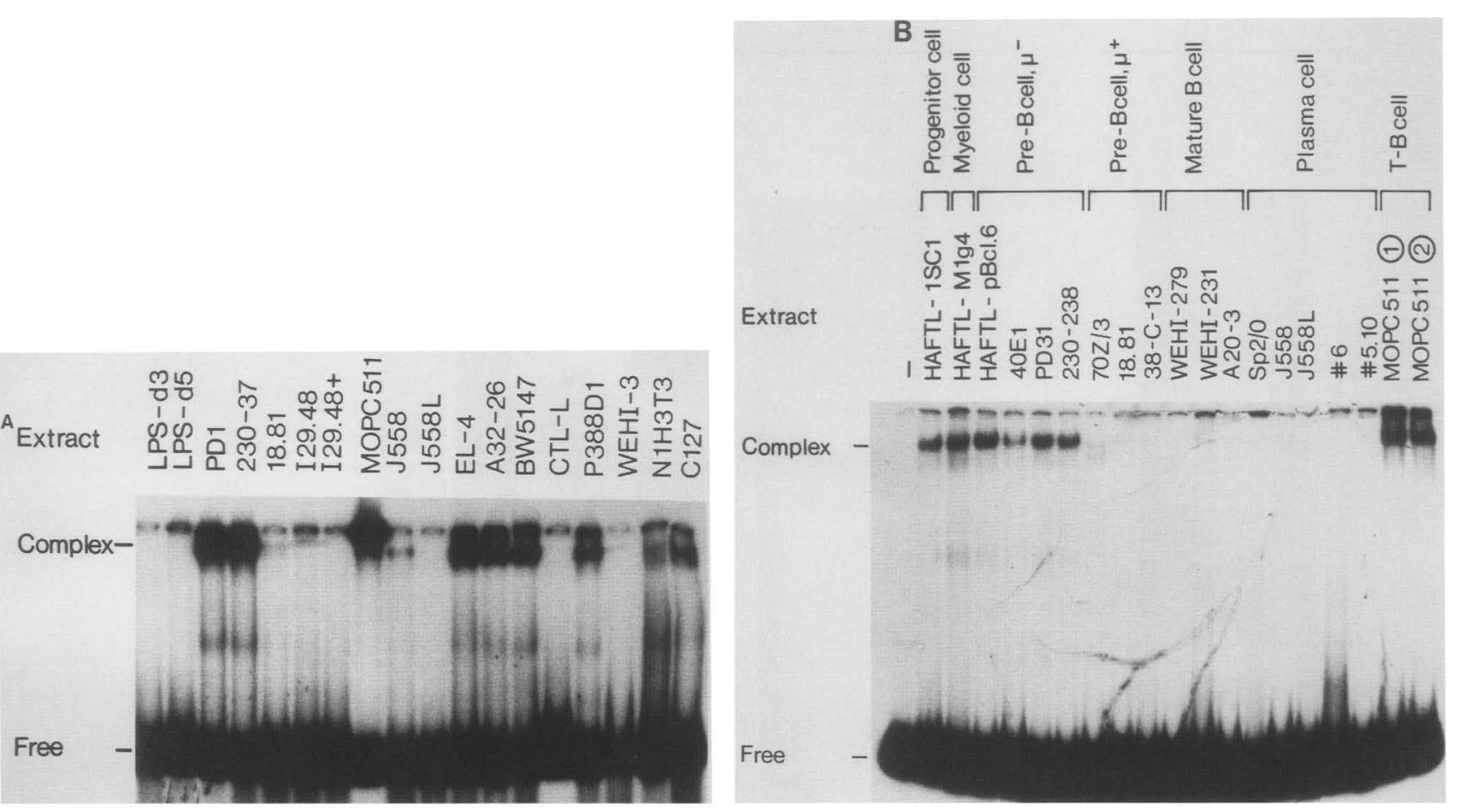

Figure 4. Cell-type-specificity of the nuclear factor NF- $\mu$ NR. Mobility shift assays were performed using $1.0 \mu \mathrm{g}$ of nuclear extracts from a variety of different cell lines and cultured spleen cells. $(A)$ Comparison of the binding activities in cells representing $\mathrm{B}$ and non-B cells. Assays were performed with $8 \mathrm{ng}$ of ${ }^{32} \mathrm{P}$-labeled $5^{\prime}-\mathrm{S} \mu(\mathrm{b})$. (Lanes LPS-d3, LPS-d5, PD31, 230-37, 18.81, I29.48, I29.48 +, $M O P C 511, J 558$, and $J 558 L$ ) Cells within the B-cell lineage; (lanes $E L-4, A 32-26$, and BW5147) T-helper cells; (lane CTL-L) cytotoxic cells; (lanes P338D1 and WEHI-3) macrophages; (lane NIH3T3) fibroblasts; (lane C127) mammary carcinoma. LPS-d3 and LPS-d5 extracts were made from dispersed spleen cells cultured for 3 or 5 days, respectively, in media containing LPS (10 $\mu \mathrm{g} / \mathrm{ml})$. I29.48+ extract was made from cells cultured with LPS. $(B)$ Comparison of the binding activities of cells representing stages within the B-cell lineage. Binding assay was performed with $10 \mathrm{ng}$ of ${ }^{32} \mathrm{P}$-labeled $3^{\prime}-\mathrm{En}$ DNA. HAFTL-1SCl is a progenitor cell line that gives rise to pre-B and myeloid cells in culture spontaneously. HAFTL-Mlg4 is a myeloid line and HAFTL-pBcl.6 is a pre-B cell line derived from HAFTL-1SC1. Pre-B cells are defined as cells that have rearranged at least part of their heavy-chain sequences but have not completed their light-chain rearrangements. The pre-B cells are subdivided further into two groups: those that express heavy-chain protein in their cytoplasm, and those that do not. Mature B cells express immunoglobulin on the cell surface. Plasma cells are capable of secreting immunoglobulin. MOPC511 is an unusual cell type that was isolated originally as a myeloma and subsequently was found to contain some characteristics of $\mathrm{T}$ cells (see text). It is represented here as a T-B cell line. (Lanes MOPC511-1 and MOPC511-2) Nuclear extracts made from two different nuclei preparations.

are responsible for enhancer suppression, the effects of binding site deletion mutants were examined in the same system (Fig. 6B). Simply by deleting either Protection 2 or Protection 3, heavy-chain enhancer suppression could be relieved in the BW5147 T-cell line; on the other hand, these mutations had little effect in J558L. Thus, binding of NF- $\mu$ NR to sequences flanking the enhancer suppresses enhancer function. These results also imply that all four binding sites are required for suppression in non-B cells. This observation may have important implications for models concerning the molecular mechanism of enhancer suppression.

\section{Discussion}

\section{Developmental regulation of a transcription regulator}

Developmental-specific protein expression provides the basis of cell-type distinction in a multicellular or- ganism: $\beta$ cells in the pancreas express insulin, red blood cells express hemoglobin, and B cells express immunoglobulin. Because all cells contain roughly the same DNA content, the expression of these proteins must be regulated in a cell-type- or developmental-specific fashion. In the case of the immunoglobulin heavy chain an important stage of this regulation occurs at the initiation of transcription, but how is transcription regulated developmentally? Here we have identified a DNAbinding protein that apparently is involved in this regulation, a negative regulator of the enhancer. Because this activity is present in cells early in the B-cell lineage and is lost as cells progress to the mature stage, this scheme provides a mechanism for how the immunoglobulin heavy-chain is regulated developmentally; the transcription regulator is regulated developmentally also. This finding supports the idea that developmental-specific protein expression occurs by a cascade of regulatory 


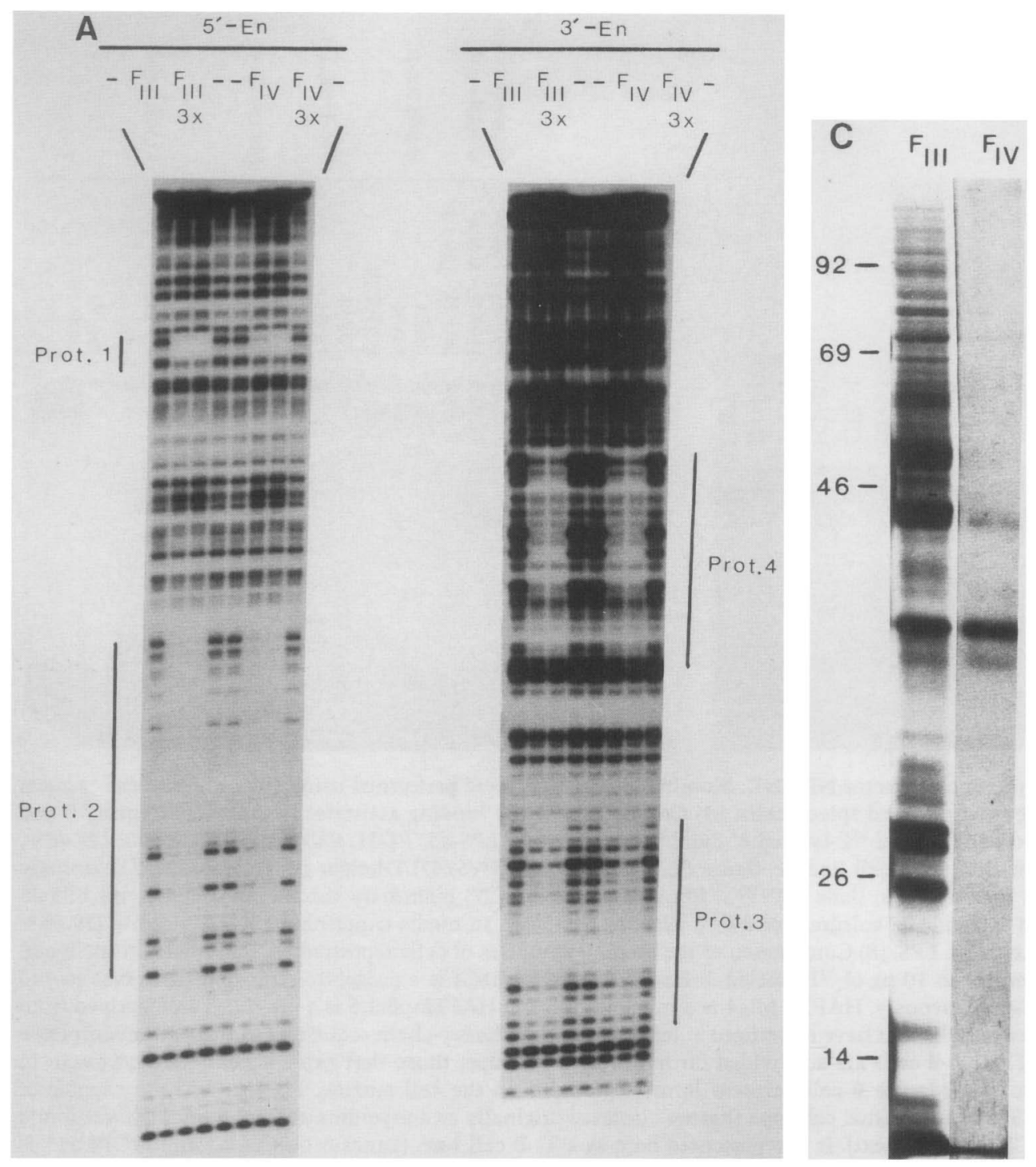

B GTCCAaAatTtTtgtcaAtcaAttigag Prot.1

-gTtTaAaAtatTtTtaAatgaAtTgagC Prot.2

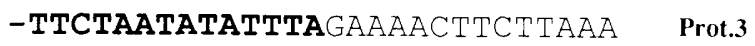

-CATtCAATtatTtTCCAATACCCGAAGT Prot.4
Figure 5. DNase protection analysis of NF- $\mu$ NR purification fractions. $(A)$ Purification fractions before $\left(\mathrm{F}_{\mathrm{II}}\right)$ and after $\left(\mathrm{F}_{\mathrm{IV}}\right)$ oligonucleotide affinity chromatography were assayed for binding-site protection as described in Methods. Reaction mixes contained 2 ng of ${ }^{32}$ P-labeled DNA fragments, $5^{\prime}$-end-labeled at the PvuII site $\left(5^{\prime}\right.$-En) or at the EcoRI site $\left(3^{\prime}\right.$-En), with or without protein extract. $F_{\text {III }}$ was added at $0.32 \mu \mathrm{g}$ or $0.96 \mu \mathrm{g}$ $(3 \times)$ and $F_{\mathrm{IV}}$ was added at $0.036 \mu \mathrm{g}$ or $0.11 \mu \mathrm{g}(3 \times)$. Regions

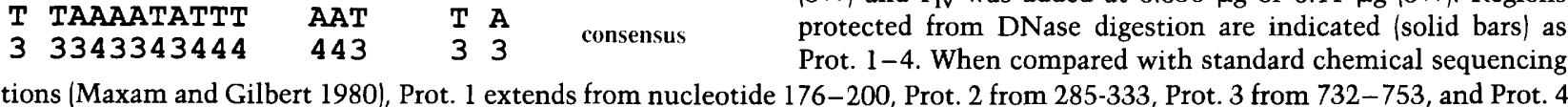

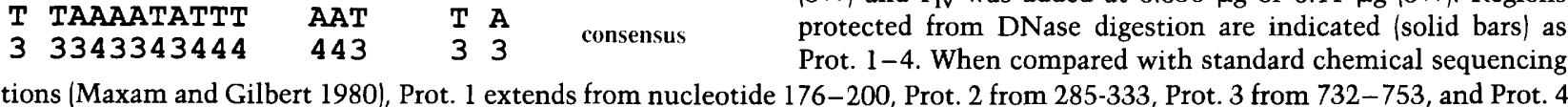
reactions (Maxam and Gilbert 1980), Prot. 1 extends from nucleotide 176-200, Prot. 2 from 285-333, Prot. 3 from $732-753$, and Prot. 4
from 788-826. (B) Alignment of the protected regions on the basis of sequence homology. Protected regions (in boldface type) and flanking sequences are aligned on the basis of homology (see text), and a consensus sequence is indicated. Nucleotides are included in the consensus sequence if they are present in at least three of the four protected regions; the numbers at the bottom indicate this frequency. $(C)$ Denaturing gel pattern of NF- $\mu$ NR purification samples. Proteins in the two purification fractions $(20 \mu l)$ were separated by standard SDS-polyacrylamide (12.5\%) gel methods (Laemmli 1970) and silver-stained to visualize the proteins (Oakley et al. $1980)$. Numbers indicate the molecular weights of marker proteins in kilodaltons.

events. Unfortunately, this only puts the problem one step back; how is the transcription regulator regulated?

A possible solution to this cascade problem comes from analysis of $k$-enhancer regulation. A positive regu- lator of the $\kappa$-enhancer, NF- $\mathrm{kB}$, which is only active in mature $B$ cells, was found to be present in inappropriate cells but in an inactive form (Sen and Baltimore 1986b). In response to cell-surface stimulation, the inactive 

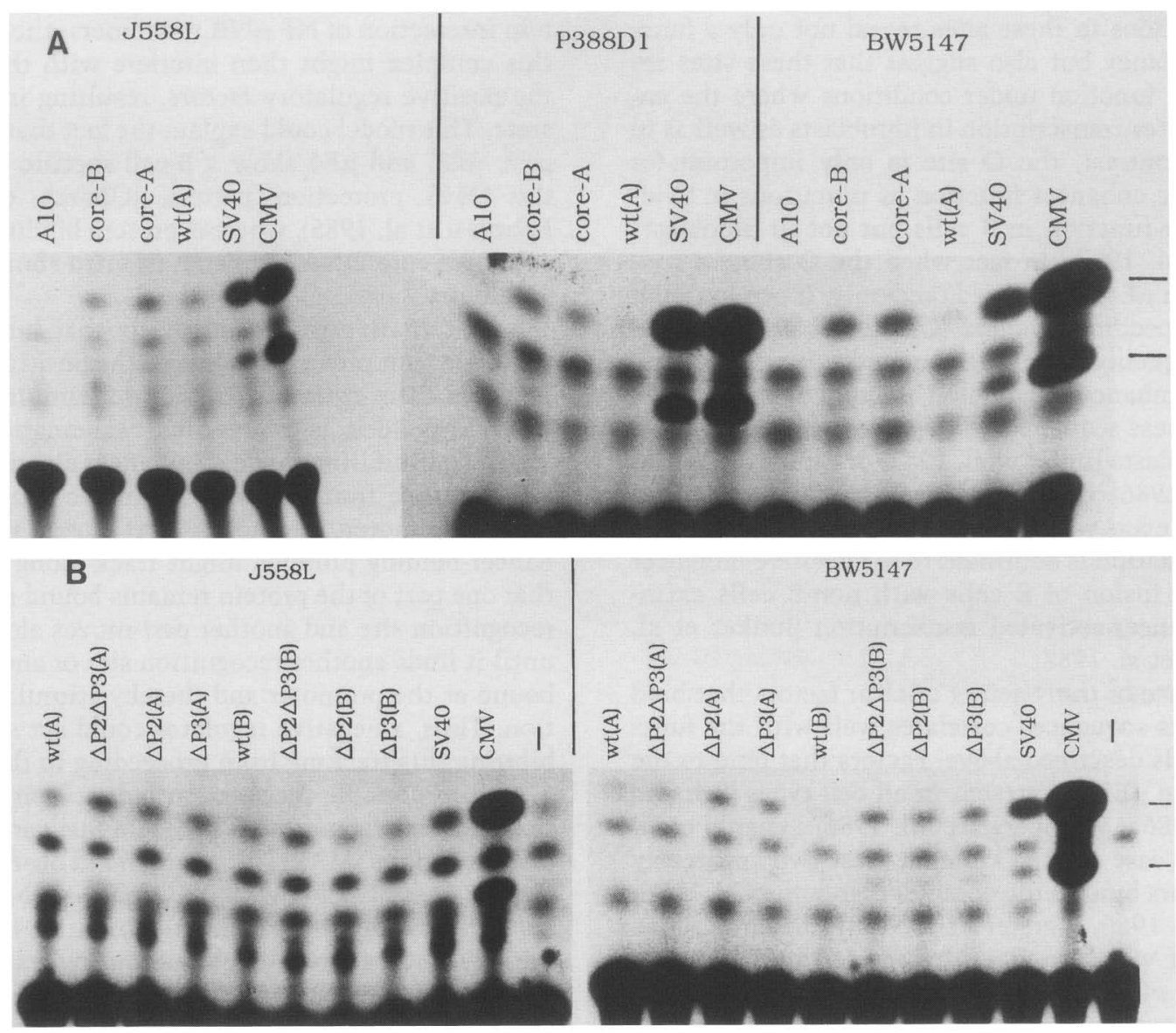

Figure 6. Functional analysis of enhancer fragments in different cell lines. Cell lines representing different cell types were transfected with DNAs containing the CAT gene driven by different enhancer constructs as described in Methods. J558L is an Ig-expressing plasma cell line; P388D1 is a macrophage line; BW5147 is a T cell line. The migration of the acetylated forms are indicated with horizontal lines. $(A)$ Comparison of the complete enhancer with the enhancer core. The DNA constructs contain different enhancers as follows: (Lanes wt) The complete 1.0-kb IgH enhancer; (lanes core) the 300-bp PvuII-EcoRI IgH enhancer core in either orientation; (lanes SV4O) the SV40 enhancer; (lanes CMV) the cytomegalovirus enhancer; (lanes $A 10$ ) no enhancer. $(B)$ Enhancer activity of NF$\mu$ NR binding site deletion mutants. The DNA constructs are as above and in addition $\triangle \mathrm{P} 2$ represents deletion of the Prot. 2 region; $\Delta \mathrm{P} 3$ deletion of Prot. 3 , and $\Delta \mathrm{P} 2 \Delta \mathrm{P} 3$ deletion of both. In all cases the $\mathrm{A}$ represents the same orientation with respect to transcription as in the normal IgH locus, and B represents the opposite orientation.

NF- $\mathrm{kB}$ could be converted to an active form by a posttranslational mechanism. Thus, inducers of differentiation could act in the absence of transcriptional controls to convert ubiquitous regulatory factors from an inactive to an active state. Therefore, it is interesting to speculate that the converse might also be true; NF- $\mu$ NR might be inactivated during progression through the $\mathrm{B}$ cell lineage by a posttranslational modification.

\section{Ig heavy-chain enhancer regulation}

The compilation of experiments analyzing the cis- and trans-acting elements of the heavy-chain enhancer clearly imply a complexity of regulation that is of a higher order than that seen in the regulation of prokaryotic transcription. The complexity of eukaryotic tran- scriptional regulation may, in part, reflect the size of the genome and the difficulty in identifying regulatory sequences with precision by the transcriptional machinery (Echols 1986). At least, in the case of the heavy-chain enhancer, it appears that proper enhancer function is mediated by three different kinds of cis-acting sequences: (1) sites like $\mu \mathrm{E} 1, \mu \mathrm{E} 2, \mu \mathrm{E} 3$, and $\mu \mathrm{E} 4$ which apparently are required for maximal enhancer function in any cell type; $(2)$ the $\mathrm{O}$ (octamer or decamer) site, involved in the positive activation of transcription in the appropriate cell type (i.e., B cells); (3) sites defined here flanking the core of the enhancer, which apparently repress enhancer function in the inappropriate cell type (e.g., $\mathrm{T}$ cells, fibroblasts, or progenitor cells). Evidence that $\mu \mathrm{E} 1, \mu \mathrm{E} 3$, and $\mu \mathrm{E} 4$ function as general enhancer elements comes from the experiments of Lenardo et al. 
(1987). Mutations in these sites reveal not only a functional redundancy but also suggest that these sites are necessary for function under conditions where the enhancer activates transcription in fibroblasts as well as in $B$ cells. In contrast, the $O$ site is only important for tissue-specific enhancer function as mutations in $\mathrm{O}$ affect enhancer function in B cells but not in fibroblasts (Lenardo et al. 1987). In fact when the O site, in conjunction with $\mu \mathrm{E} 4$, is repeated tandemly, it can function as a tissue-specific enhancer (Gerster et al. 1987). Finally, the sequences flanking the core enhancer are important for enhancer repression in inappropriate cells; deletion of these sequences allows the enhancer to function in fibroblasts (Imler et al. 1987) or kidney cells (Kadesch et al. 1986), or in T cells and macrophages as reported here, even with a wild-type $O$ site. Apparently negative regulation is dominant to the positive-enhancer elements, as fusion of B cells with non-B cells extinguishes enhancer-activated transcription (Junker et al. 1988; Zaller et al. 1988).

The presence of trans-acting nuclear factors that bind to the various sequences correlates well with the functional analysis described above. Factors that bind to the $\mu E 1, \mu E 2$, and $\mu E 3$ are present in all cell types /Sen and Baltimore 1986a; Weinberger et al. 1986; Lenardo et al. 1987). In the case of the O site, at least two apparently distinct factors bind to the octamer (Landolfi et al. 1986; Staudt et al. 1986; Gerster et al. 1987; Lenardo et al. 1987), one of which is present only in lymphoid cells. On the basis of the discussion of the cis-acting requirements, this implies that this lymphoid-specific factor is important for positive enhancer function. In this paper we identified a new nuclear factor, NF- $\mu N R$, that binds to sequences flanking the core enhancer. The binding sites determined here correlate very well with the negative-regulatory elements identified by deletion analysis (Imler et al. 1987). The absence of this factor in all cells expressing heavy-chains and the requirement of its binding site for tissue specificity argues for its role in repressing enhancer function, especially in $\mathrm{T}$ cells.

Peterson et al. (1986) identified a number of proteins that bind in and around the heavy-chain enhancer. However, NF- $\mu$ NR is apparently distinct from the proteins they described because their proteins were ubiquitously present, even in plasmacytomas, and the binding sites that were determined with partially purified proteins (Peterson and Calame 1987) are distinct from those reported here. Certainly, the complexity of specific DNAprotein interactions in the region is astonishing.

\section{Models for enhancer repression}

A crucial question is how does binding to these enhancer-flanking sequences by NF- $\mu N R$ preclude enhancer function; several models are depicted schematically in Figure 7A. One possible mechanism, termed 'binding-site occlusion', is that binding of NF- $\mu$ NR both $5^{\prime}$ and $3^{\prime}$ of the enhancer might results in the formation of a large DNA-protein complex through protein-pro- tein interaction of NF- $\mu$ NR monomers; the formation of this complex might then interfere with the binding of the positive regulatory factors, resulting in an inactive state. This model could explain the fact that in vivo $\mu E 1$, $\mu \mathrm{E} 2, \mu \mathrm{E} 3$, and $\mu \mathrm{E} 4$ show a B-cell-specific alteration in the DMS protection pattern /Church et al. 1985; Ephrussi et al. 1985), whereas protein binding to isolated enhancer core DNA segments in vitro shows no tissuespecificity.

An alternative to this model is that binding of NF$\mu N R$ does not prevent binding of the positive factors but prevents them from functioning to stimulate transcription. This idea is represented schematically in the 'tracking inhibition model'. Enhancer elements function at a distance from a promoter but do function on the closest promoter. To find the next closest promoter, enhancer-binding proteins might track along the DNA so that one part of the protein remains bound to its cognate recognition site and another part moves along the DNA until it finds another recognition site or another protein bound at the promoter and thereby stimulate transcription. Thus, a negative regulator could act simply by inhibiting this tracking from proceeding to the promoter.

A third possible mechanism is based on the observation that topoisomerase II sites and nuclear matrix association regions (MARs) often are found near enhancer elements (e.g., Cockerill and Garrard 1986; Gasser and Laemmli 1986). These elements might be important for the alteration of tortional stress during transcription in the case of topoisomerase II sites, or for the anchorage of expressed genes in a region of high transcription factor concentration around the nuclear matrix. Recently, Cockerill et al. (1987) found that the heavy-chain enhancer also is associated with the nuclear matrix; in fact the fragments bound to the nuclear matrix are the same fragments we find bound by NF- $\mu$ NR. Interestingly, the NF- $\mu$ NR binding sites both $5^{\prime}$ and $3^{\prime}$ of the enhancer overlap potential MAR consensus sites and topoisomerase II consensus sites (Fig. 7B). NF- $\mu$ NR then might repress enhancer function by inhibiting changes in torsional stress or by inhibiting matrix attachment or both. Binding of NF- $\mu$ NR to the sequences flanking the enhancer prevents the association between the nuclear matrix and the enhancer by covering the matrix attachment sequences, resulting in an inactive state; in the absence of NF- $\mu$ NR the matrix attachment sequences are free to bind to the nuclear matrix thereby bringing the enhancer into a region of high transcription factor concentration, activating transcription. This mechanism can be thought of generally as a change in compartmentalization in which genes are kept in active or inactive locations within the nucleus. Clearly, additional mechanisms are possible and the elucidation of enhancer regulation awaits further experiments into how enhancers function to stimulate transcription.

Thus, in the case of the immunoglobulin heavy-chain enhancer, multiple protein-DNA interactions are important for the fine-tuning of enhancer function. It appears that maximal enhancer activity requires the presence of positive factors, some of which are present in all 
A $_{\text {ACtive }}$
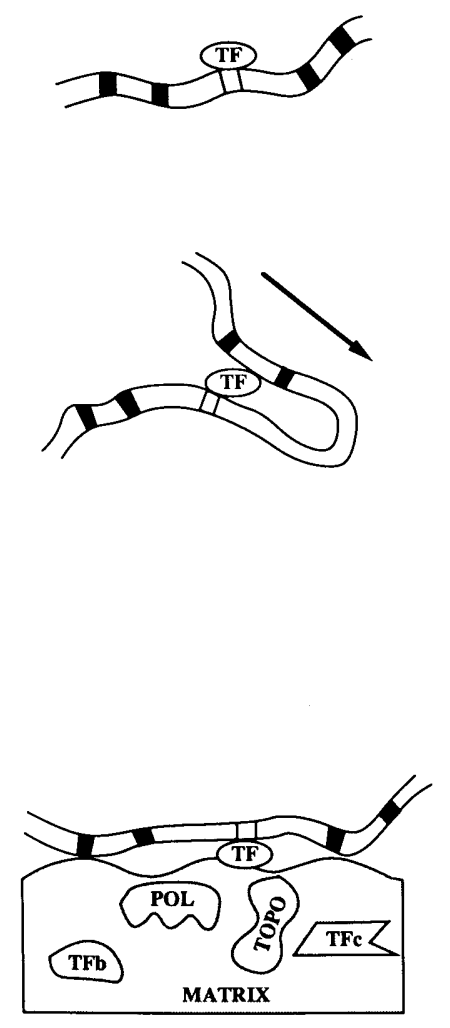

INACTIVE
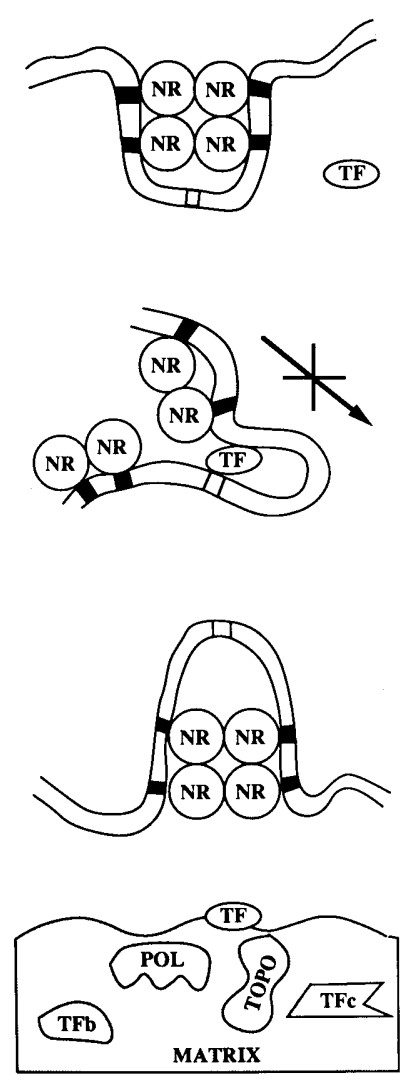

Binding Site

Occlusion
Tracking

Inhibition
Change in

Compartmentalization

B
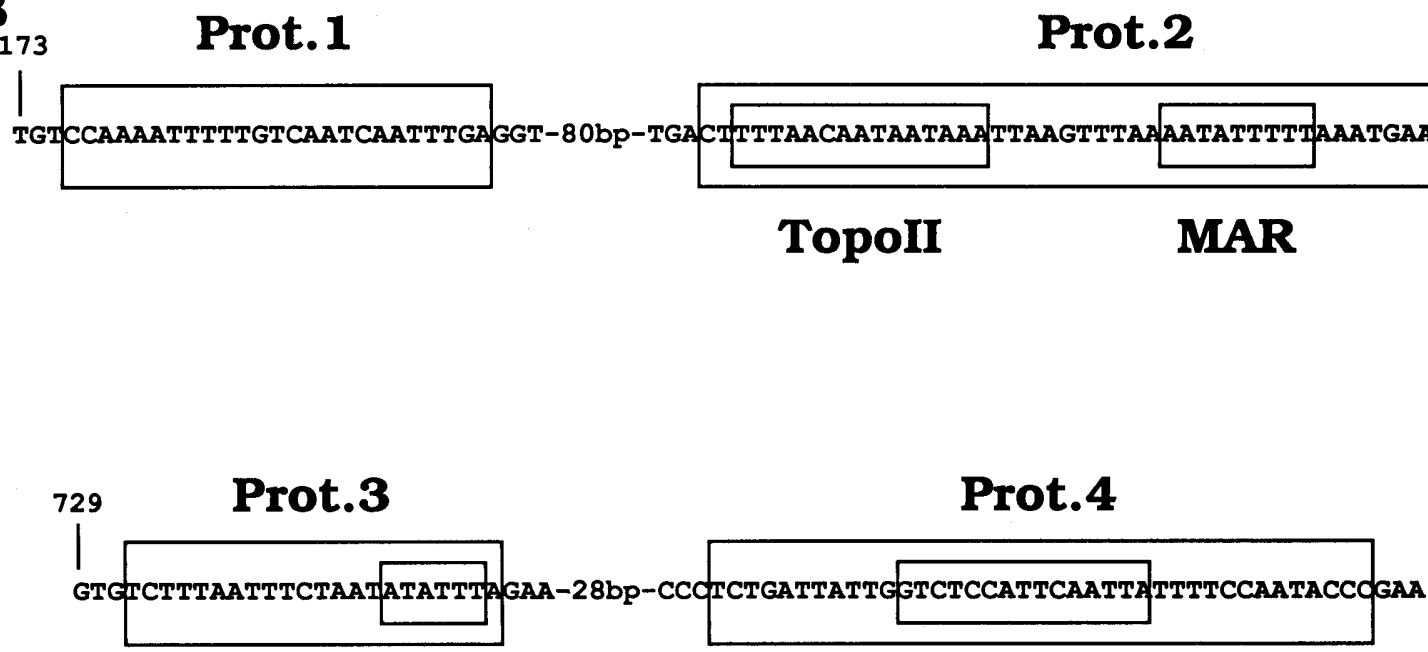

MAR

TopoII

Figure 7. Models for the mechanism of enhancer inhibition. (A) Three models for a molecular mechanism of IgH-enhancer inhibition (see text). (B) The presumptive binding sites of various nuclear factors. The four regions protected by NF- $\mu$ NR binding as determined here are indicated. In addition, regions that might bind to the nuclear matrix or nuclear scaffold (MAR) (Cockerill and Garrard 1986) and potential cleavage sites for topoisomerase II (TopoII) are indicated, which match the consensus of Sander and Hsieh (1985) at 13 of 15 positions. The numbers above the sequences are base pairs from the 5' XbaI site. 
cells and others restricted to expressing cells. In addition, negative regulation of the enhancer is also an important mechanism for the control of heavy-chain expression. Negative-enhancer regulation may be a general mechanism for tissue-specific expression as negativeregulatory elements also have been found that are associated with the insulin 1 gene enhancer (Laimins et al. 1986; Nir et al. 1986), the $\beta$-interferon gene enhancer (Goodbourn et al. 1986), and viral enhancers in embryonic stem cells (Gorman et al. 1985), and mouse mammary epithelial cells (Langer and Ostrowski 1988).

\section{Methods}

\section{Cell lines}

The following cell lines (for descriptions see Sakaguchi et al. 1986; Staudt et al. 1986; and the American Type Culture catalog of cell lines and hybridomas) were provided kindly by $\mathrm{F}$. Melchers, unless otherwise indicated: HAFTL-1SC1 represents cells early in the hemopoietic lineage; HAFTL-M1g4 and HAFTL-pBc1.6 are subclones of HAFTL-1SC1, which have apparently differentiated to the myeloid and pre-B-cell stage, respectively; 40E1, PD31, and 230-238 are pre-B cell lines that do not express heavy chain; 70Z/3, 18.81, and 38-C-13 are pre-B cell lines that do express heavy chain; WEHI-231, WEHI-279, and $\mathrm{A} 20-3$ are mature B cell lines; Sp2/0, J558 (from U. Chen), and J558L (from U. Chen) are plasmacytomas; 6 and 5.10 are hybridoma lines derived from fusion of LPS-stimulated splenic B cells with X63 (from U. Chen); MOPC511 is a myeloma cell line that has rearranged its $\mathrm{T}$-cell receptor genes as well as all of its immunoglobulin genes (from K. Karjalainen); I29.48 is a B-cell lymphoma (from U. Chen); EL-4, BW5147, and A32-26 are $\mathrm{T}$ cell lines; CTL-L is a cytotoxic $\mathrm{T}$ cell line; P388D1 and WEHI-3 are macrophage cell lines, NIH-3T3 is a fibroblast line; and $\mathrm{C} 127$ is a mammary carcinoma cell line.

\section{Nuclear extract preparation and factor purification}

Nuclei were isolated by a modification of the protocol of Schibler et al. (1983). Cells $\left(\sim 10^{9}\right)$ were grown to near confluence and pelleted, then resuspended with $10 \mathrm{ml}$ buffer $\mathrm{A}$ [5.4\% sucrose, $60 \mathrm{mM} \mathrm{KCl}, 15 \mathrm{mM} \mathrm{NaCl}, 15 \mathrm{~mm} \mathrm{HEPES} / \mathrm{KOH}$ (pH 7.9), 2 mM EDTA, $0.4 \mathrm{~mm}$ spermidine, $2 \mathrm{~mm}$ DTT, $0.1 \%$ NP-40]. Cells were homogenized with 2-5 strokes of a Dounce homogenizer with a type-A pestle and incubated on ice for 5-20 min, depending on the cell line. Lysed cells were layered on $25 \mathrm{ml}$ buffer B /same as buffer A except $30 \%$ sucrose and no NP-40) and the nuclei were pelleted at $1300 \mathrm{~g}$ for $15 \mathrm{~min}$. Nuclei were resuspended with $5 \mathrm{ml}$ buffer D (same as buffer B except $36 \%$ sucrose and $0.1 \mathrm{~mm}$ EDTA) and pelleted through $20 \mathrm{ml}$ buffer $\mathrm{D}$ as above. Purified nuclei were resuspended with $0.5 \mathrm{ml}$ buffer $\mathrm{E}$ [ $50 \%$ glycerol, $20 \mathrm{mM}$ Tris- $\mathrm{HCl}$ (pH 8.0), $75 \mathrm{~mm}$ $\mathrm{NaCl}, 0.5 \mathrm{~mm}$ EDTA, $1 \mathrm{~mm}$ DTT, $0.1 \mathrm{~mm}$ PMSF], aliquoted, and then frozen immediately in liquid $\mathrm{N}_{2}$, and stored at $-70^{\circ} \mathrm{C}$.

Nuclear extracts generally contained $0.2-1.0 \mathrm{mg} / \mathrm{ml}$ of protein and were prepared by adding $0.3 \mathrm{M} \mathrm{NaCl}$ to purified nuclei; following a $30-\mathrm{min}$ incubation on ice, the nuclear debris was removed by centrifugation for $10 \mathrm{~min}$ in a microfuge. For the DNase I protection experiments, the PD31 nuclear extract was purified first by DEAE-Sephacel and heparin-agarose chromatography. Further purification using oligonucleotide-affinity chromatography was performed essentially as described by Kadonaga and Tjian (1986). Details of NF- $\mu$ NR purification will be published elsewhere.

\section{Plasmids and DNA fragments}

DNA fragments (see Fig. 1) were prepared as follows: Enhancer fragments were isolated from pUC/IgHE-X1.0 /a plasmid that contains the 991-bp XbaI mouse enhancer fragment subcloned into pUC19); 5 '-En (381 bp) by digestion with $X b a \mathrm{I}$ and PvuII; end fragment ( $301 \mathrm{bp}$ ) by digestion with $P v u I I$ and $E c o$ RI, $3^{\prime}$-En ( $309 \mathrm{bp}$ ) by digestion with EcoRI and $\mathrm{XbaI}$; $\mathrm{S} \mu$ fragments from pUC/ $\mu 0.75$ (a plasmid containing a 0.75 -kb HindIII fragment subcloned into pUC19, from the plasmid $\mathrm{pR} \mu \mathrm{Sal}$ kindly provided by K. Karjalainen), 5'-S $\mu(\mathrm{a})(205 \mathrm{bp})$ and $5^{\prime}-\mathrm{S} \mu(\mathrm{b})(500 \mathrm{bp})$ by digestion with AccI and HindIII; and from pUC $\mu 1.3$ (a plasmid containing a 1.3-kb HindIII fragment from $\mathrm{pR} \mu \mathrm{Sal}$ subcloned into pUC19), $5^{\prime}-\mathrm{S} \mu(\mathrm{c})$ and $\mathrm{S} \mu$ by digestion with $\mathrm{SacI}$ and HindIII; S $\gamma 2 \mathrm{~b}$ fragments were three different fragments between $350 \mathrm{bp}$ and $500 \mathrm{bp}$ from pSy2b-E6.6 (a gift of W. Dunnick) by digestion with PvuII. All fragments were isolated following agarose gel electrophoresis by electroelution and quantitated by relative ethidium bromide staining intensity compared with a DNA standard of known concentration. DNA fragments were radioactively labeled with $\mathrm{T} 4$ polynucleotide kinase and $\left[\gamma^{-32}\right.$ P]ATP or with Escherichia coli DNA polymerase I and $\left[\alpha-{ }^{32}\right.$ P $]$ dNTPs by standard procedures (Maniatis et al. 1982).

All plasmids used for the transfection experiments are derivatives of pA10CAT (Laimins et al. 1982), which contains the chloramphenicol acetyltransferase gene flanked by the SV40 early promoter and poly(A) addition site. pSV2CAT (Gorman et al. 1982) is a derivation of pA10CAT, which contains the SV40 enhancer. pCMV-CAT contains the human cytomegalovirus enhancer (Boshart et al. 1985). pC $\mu-5^{\prime}$-CAT contains the 991-bp $X b a \mathrm{I}$ immunoglobulin heavy-chain-enhancer fragment inserted into the $\mathrm{XbaI}$ site of pCAT-2 polylinker in the same orientation with respect to the direction of transcription as in the heavychain locus (Mosthaf et al. 1985). pCAT-core(A) and pCATcore(B) were constructed by insertion of the 301-bp PvuIIEcoRI immunoglobulin heavy-chain-core enhancer fragment into the $\mathrm{XbaI}$ site of pCAT-2 polylinker following filling-in and $X b a I$ linker addition; the two constructs represent insertion in either orientation, where A contains insertions in the same orientation as in $\mathrm{pC} \mu-5^{\prime}$-CAT.

Plasmids containing binding-site deletion mutants were constructed by first making mutations in the 991-bp enhancer fragment to provide convenient restriction sites using the MutaGene Mutagenesis Kit (Bio-Rad). BgIII restriction sites were created at positions 277 (nucleotides from 5'-XbaI site) and 341 flanking the Protection 2 region, and $X$ hoI restriction sites were created at positions 697 and 759 flanking the Protection 3 region; binding-site deletion mutants then were constructed simply by digestion with the appropriate enzymes and recirculation of the vector-containing DNA fragment.

\section{Mobility shift assay}

DNA-binding reactions $(20 \mu \mathrm{l})$ contained $10 \mathrm{~mm}$ Tris- $\mathrm{HCl} / \mathrm{pH}$ 7.5), $10 \mathrm{~mm} \mathrm{NaCl}, 10 \mathrm{mM} \mathrm{KCl}, 10 \mathrm{mM} \mathrm{MgCl}_{2}, 5 \mathrm{mM} \mathrm{ZnCl}_{2}, 0.5$ mM EDTA, $10 \%$ glycerol or $4 \%$ Ficoll, $0.1 \mathrm{mg} / \mathrm{ml}$ of poly[d(I-C)], nuclear extract (added last), and test DNA as indicated. Following a 30 -min incubation at room temperature, binding reactions were loaded directly onto a $4 \%$ acrylamide gel and electrophoresed for 2-2.5 hr as described (Fried and Crothers 1981; Garner and Revzin 1981). In some cases, binding activity was quantitated from autoradiograms by scanning laser densitometry.

\section{DNase protection experiments}

The ${ }^{32} \mathrm{P}$-labeled test DNA ( 1 ng) was incubated with the par- 
tially purified protein extract for $15 \mathrm{~min}$ at room temperature in $25 \mathrm{mM}$ HEPES/KOH (pH 7.9), $20 \%$ glycerol, $0.1 \mathrm{M} \mathrm{KCl}, 0.1 \%$ $\mathrm{NP}-40,10 \mu \mathrm{ZnCl}_{2}, 12 \mathrm{mM} \mathrm{MgCl} 2,2 \%$ polyethyleneglycol, and $2 \mu \mathrm{g}$ of poly[d(I-C)] $(50 \mu \mathrm{l})$, at which time an equal volume of 10 $\mathrm{mM} \mathrm{MgCl}, 5 \mathrm{mM} \mathrm{CaCl}_{2}$ was added and incubation continued for $1 \mathrm{~min}$. The DNA was digested with DNase I [ $4 \mathrm{ng}$, freshly diluted in cold double-distilled $\mathrm{H}_{2} \mathrm{O}$, (BRL)] for $90 \mathrm{sec}$ at room temperature. The reaction was stopped by the addition of an equal volume $(100 \mu \mathrm{l})$ of $20 \mathrm{~mm}$ EDTA/ $\mathrm{NaOH}(\mathrm{pH} 8.0), 1 \%$ SDS, $0.2 \mathrm{M} \mathrm{NaCl}$, and $2 \mu \mathrm{g}$ of proteinase $\mathrm{K}$. The DNA was purified by phenol/chloroform and ether extractions and isopropanol precipitation. The DNA samples were electrophoresed on an $8 \%$ denaturing polyacrylamide gel and fragment sizes were determined by comparison to DNA treated with standard sequencing reactions as described (Maxam and Gilbert 1980).

\section{Cell transfection and CAT assay}

Transient expression of transcriptional enhancer activity was measured using cells transfected by the DEAE-dextran and DMSO shock method (Picard and Schaffner 1985). Cells $\left(1-2 \times 10^{7}\right)$ were washed once with Tris-buffered saline (TBS) and transfected with $20 \mu \mathrm{g}$ recombinant DNA containing either the SV40 enhancer, the human cytomegalovirus enhancer, or segments of the immunoglobulin heavy-chain enhancer linked to the CAT gene. Cells were incubated with DNA for $30 \mathrm{~min}$, washed once with TBS, then subjected to $20 \%$ DMSO shock for $4 \mathrm{~min}$, washed, and resuspended with fresh media. Two days after transfection, cells were harvested and CAT assays were performed as described (Köhrer et al. 1985).

\section{Acknowledgments}

We thank S. Bauer, S. Carson, C. Coleclough, K. Karjalainen, and F. Melchers for critical reading of this manuscript. We also thank W. Dunnick, B. Fleckenstein, I. Grummt, P. Gruss, W. Schaffner, and A. Traunecker for providing us with plasmids; and K. Karjalainen and F. Melchers for cell lines. We would especially like to thank B. Grossenbacher, D. Lenig and U. Kämpf for expert technical assistance, C. Plattner and J. Millar for excellent secretarial assistance, and H.-P. Stahlberger for art work. The Basel Institute for Immunology was founded and is supported by F. Hoffmann-La Roche Ltd. Co., Basel, Switzerland.

\section{References}

Augereau, P. and P. Chambon. 1986. The mouse immunoglobulin heavy-chain enhancer: effect on transcription in vitro and binding of proteins present in HeLa and lymphoid B cell extracts. $E M B O$ J. 5: 1791-1797.

Banerii, J., L. Olson, and W. Schaffner. 1983. A lymphocyte-specific cellular enhancer is located downstream of the joining region in immunoglobulin heavy-chain genes. Cell 33: 729740.

Boshart, M., F. Weber, G. Jahn, K. Dorsch-Häsler, B. Fleckenstein, and W. Schaffner. 1985. A very strong enhancer is located upstream of an immediate early gene of human cytomegalovirus. Cell 41: 521-530.

Chandler, V.L., B.A. Maler, and K.R. Yamamoto. 1983. DNA sequences bound specifically by glucocorticoid receptor in vitro render a heterologous promoter hormone responsive in vivo. Cell 33: 489-499.

Church, G.M., A. Ephrussi, W. Gilbert, and S. Tonegawa. 1985. Cell-type-specific contacts to immunoglobulin enhancers in nuclei. Nature 313: 798-801.
Cockerill, P.N. and W.T. Garrard. 1986. Chromosomal loop anchorage of the kappa immunoglobulin gene occurs next to the enhancer in a region containing topoisomerase II sites. Cell 44: 273-282.

Cockerill, P.N., M.-H. Yuen, and W.T. Garrard. 1987. The enhancer of the immunglobulin heavy chain locus is flanked by presumptive chromosomal loop anchorage elements. $J$. Biol. Chem. 262: 5394-5397.

Echols, H. 1986. Multiple DNA protein interactions governing high precision DNA transactions. Science 233: 1050-1056.

Ephrussi, A., G.M. Church, S. Tonegawa, and W. Gilbert. 1985. B-lineage-specific interactions of an immunoglobulin enhancer with cellular factors in vivo. Science 227: 134-140.

Fried, M. and D.M. Crother. 1981. Equilibrium and kinetics of Lac repressor operator interactions by polyacrylamide gel electrophoresis. Nucleic Acids Res. 9: 6505-6525.

Garner, M.M. and A. Revzin. 1981. A gel electrophoresis method for quantifying the binding of proteins to specific DNA regions: application to components of the E. coli lactose operon regulatory system. Nucleic Acids Res. 9: 30473060.

Gasser, S.M. and U.K. Laemmli. 1986. Cohabitation of scaffoldbinding regions with upstream/enhancer elements of three developmentally regulated genes of $D$. melanogaster. Cell 46: $521-530$.

Gerster, T., P. Matthias, M. Thali, J. Jiricny, and W. Schaffner. 1987. Cell-type-specificity elements of the immunoglobulin heavy chain gene enhancer. EMBO J. 6: 1323-1330.

Gillies, S.D., S.L. Morrison, V.T. Oi, and S. Tonegawa. 1983. A tissue-specific- transcription enhancer element is located in the major intron of a rearranged immunoglobulin heavy chain gene. Cell 33: 717-728.

Goodbourn, S., H. Hurstein, and T. Maniatis. 1986. The human $\beta$-interferon gene enhancer is under negative control. Cell 45: $601-610$.

Gorman, C.M., L.F. Moffat, and B.H. Howard. 1982. Recombinant genomes which express chloramphenicol acetyltransferase in mammalian cells. Mol. Cell. Biol. 2: 1044-1051.

Gorman, C.M., P.W.J. Rigby, and D.P. Lane. 1985. Negative regulation of viral enhancers in undifferential embryonic stem cells. Cell 42: 519-526.

Grosschedl, R. and D. Baltimore. 1985. Cell-type specificity of immunoglobulin gene expression is regulated by at least three DNA sequences elements. Cell 41: 885-897.

Hood, L., D. McKean, V. Farnsworth, and M. Potter. 1973. Mouse immunoglobulin chains. A survey of the amino-terminal sequences of $\kappa$ chains. Biochemistry 12: 741-749.

Imler, J.-L., C. Lemaire, C. Wasylyk, and B. Wasylyk. 1987. Negative regulation contributes to tissue specificity of the immunoglobulin heavy-chain enhancer. Mol. Cell. Biol. 7: 2558-2567.

Junker, J., V. Nielsen, P. Matthias, and D. Picard. 1988. Both immunoglobulin promoter and enhancer sequences are targets for suppression in myeloma-fibroblast hybrid cells. EMBO J. 7: 3093-3098.

Kadesch, T., P. Zervos, and D. Ruezinsky. 1986. Functional analysis of the murine IgH enhancer: evidence for negative control of cell-type-specificity. Nucleic Acids Res. 14: 8209-8221.

Kadonaga, J.T. and R. Tjian. 1986. Affinity purification of sequence-specific DNA binding proteins. Proc. Natl. Acad. Sci. 83: 5889-5893.

Khoury, G. and P. Gruss. 1983. Enhancer elements. Cell 33: 313-314.

Köhrer, K., I. Grummt, and I. Horak. 1985. Functional RNA polymerase II promoters in solitary retroviral long terminal 
repeats (LTR-IS elements). Nucleic Acids Res. 13: 26312645.

Laemmli, U.K. 1970. Cleavage of structural proteins during the assembly of the head of bacteriophage T4. Nature 227: 680685.

Laimins, L.A., G. Khoury, C. Gorman, B. Howard, and P. Gruss. 1982. Host-specific activation of transcription by tandem repeats from simian virus 40 and Moloney murine sarcoma virus. Proc. Natl. Acad. Sci. 79: 6453-6457.

Laimins, L., M. Holmgren-König, and G. Khourny. 1986. Transcriptional 'silencer' element in rat repetitive sequences associated with the rat insulin 1 gene locus. Proc. Natl. Acad. Sci. 83: 3151-3155.

Landofli, N.F., J.D. Capra, and P.W. Tucker. 1986. Interaction of cell-type-specific nuclear proteins with immunoglobuln $\mathrm{V}_{\mathbf{H}}$ promoter region sequences. Nature 323: 548-551.

Langer, S.J. and M.C. Ostrowski. 1988. Negative regulation of transcription in vitro by a glucocorticoid response element is mediated by a trans-acting factor. Mol. Cell. Biol. 8: $3872-3881$.

Lenardo, M., J. Pierce, and D. Baltimore. 1987. Protein-binding sites in Ig gene enhancers determine transcriptional activity and inducibility. Science 236: 1573-1577.

Maniatis, T., E.F. Fritsch, and J. Sambrook. 1982. Molecular cloning: A laboratory manual. Cold Spring Harbor Laboratory, Cold Spring Harbor, New York.

Mason, J.O., G.T. Williams, and M.S. Neuberger. 1985. Transcription cell-type specificity is conferred by an immunoglobulin $\mathrm{V}_{\mathrm{H}}$ gene promoter that includes a functional consensus sequences. Cell 41: 479-487.

Maxam, A.M. and W. Gilbert. 1980. Sequencing end-labeled DNA with basic-specific chemical cleavage. Methods Enzymol. 65: 499-560.

Mercola, M., X.-F. Wang, J. Olsen, and K. Calame. 1983. Transcriptional enhancer elements in the mouse immunoglobulin heavy-chain locus. Science 221: 663-665.

Mercola, M., J. Goverman, C. Mirell, and K. Calame. 1985. Immunoglobulin heavy-chain enhancer requires one or more tissue-specific factors. Science 227: 266-270.

Mosthaf, L., M. Pawlita, and P. Gruss. 1985. A viral enhancer element specifically active in human haemopoietic cells. Nature 315: 597-600.

Neuberger, M.S. 1983. Expression and regulation of immunoglobulin heavy-chain gene transfected into lymphoid cells. EMBO I. 2: 1373-1378.

Nir, U., M.D. Walker, and W.J. Rutter. 1986. Regulation of rat insulin 1 gene expression: evidence for negative regulation in nonpancreatic cells. Proc. Natl. Acad. Sci. 83:31803184.

Oakley, B.R., D.R. Kirsch, and N.R. Morris. 1980. A simplified ultrasensitive silver stain for detecting proteins in polyacrylamide gels. Anal. Biochem. 105: 361-363.

Peterson, C.L. and K.L. Calame. 1987. Complex protein binding within the mouse immunoglobulin heavy-chain enhancer. Mol. Cell. Biol. 7: 4194-4203.

Peterson, C.L., K. Orth, and K.L. Calame. 1986. Binding in vitro of multiple cellular proteins to immunoglobulin heavychain enhancer. Mol. Cell. Biol. 6: 4168-4178.

Picard, D. and W. Schaffner. 1985. Cell-type preference of immunoglobulin $\kappa$ and $\lambda$ gene promoters. EMBO I. 4: 28312838.

Rossi, P. and B. deCrombrugghe. 1987. Identification of a cellspecific transcriptional enhancer in the first intron of the mouse $\alpha 2$ (type I) collagen gene. Proc. Natl. Acad. Sci. 84: $5590-5594$.

Sakaguchi, N., C.N. Berger, and F. Melchers. 1986. Isolation of a cDNA copy of an RNA species expressed in murine pre-B cells. $E M B O ~ J$. 5: 2139-2147.

Sander, M. and T.S. Hsieh. 1985. Drosophila topoisomerase II double-stranded DNA cleavage: analysis of DNA sequence homology at the cleavage site. Nucleic Acids Res. 3: 10571072.

Schibler, U., O. Hagenbüchle, P.K. Wellauer, and A.C. Pittet. 1983. Two promoters of different strengths control the transcription of the mouse alpha-amylase gene amy-1a in the parotid gland and the liver. Cell 33: 501-508.

Schlokat, U., D. Bohmann, H. Schöler, and P. Gruss. 1986. Binding in vitro of multiple cellular proteins to immunoglobulin heavy-chain enhancer DNA. EMBO I. 5: 32513258.

Schöler, H.R. and P. Gruss. 1984. Specific interaction between enhancer-containing molecules and cellular components. Cell 36: 403-411.

1985. Cell-type-specific transcriptional enhancement in vitro requires the presence of trans-acting factors. $E M B O J$. 4: 3005-3013.

Sen, R. and D. Baltimore. 1986a. Multiple nuclear factors interact with the immunoglobulin enhancer sequences. Cell 46: 705-716.

- 1986b. Inducibility of $\kappa$ immunoglobulin enhancerbinding protein NF-кB by a posttranslational mechanism. Cell 47: 921-928.

Singh, H., R. Sen, D. Baltimore, and P.A. Sharp. 1986. A nuclear factor that binds to a conserved motif in transcriptional control elements of immunoglobulin genes. Nature 319: $154-158$.

Staudt, L.M., H. Singh, R. Sen, T. Wirth, P.A. Sharp, and D. Baltimore. 1986. A lymphoid-specific protein binding to the octamer motif of immunoglobulin genes. Nature 323: 640643.

Traunecker, A., M. Kiefer, Z. Dembić, M. Steinmetz, and K. Karjalainen. 1986. Rearrangements of $T$-cell receptor loci can be found only rarely in B lymphoid cells. Eur. J. Immunol. 16: 430-434.

Walker, M.D., T. Edlund, A.M. Boulet, and W.J. Rutter. 1983. Cell-specific expression controlled by the 5 -flanking region of insulin and chymotrypsin genes. Nature 306: 557-561.

Wasylyk, C. and B. Wasylyk. 1986. The immunoglobulin heavy-chain B-lymphocyte enhancer efficiently stimulates transcription in nonlymphoid cells. EMBO I. 5: 553-560.

Weinberger, J., D. Baltimore, and P.A. Sharp. 1986. Distinct factors bind to apparently homologous sequences in the immunoglobulin heavy chain enhancer. Nature 322: 846-848.

Zaller, D.M., H. Yu, and L.A. Eckhardt. 1988. Genes activated in the presence of an immunoglobulin enhancer or promoter are negatively regulated by a T-lymphocyte cell line. Mol. Cell. Biol. 8: 1932-1939. 


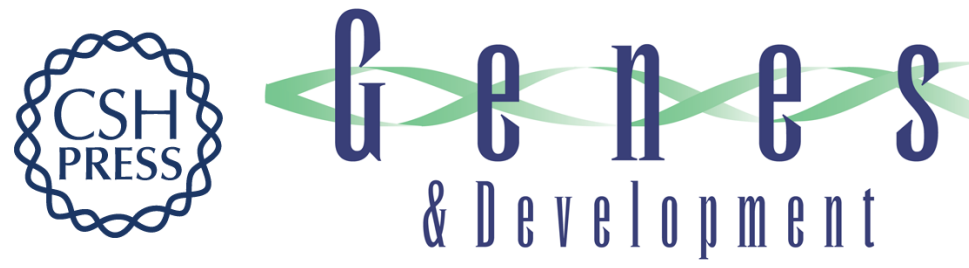

\section{A developmental-specific factor binds to suppressor sites flanking the immunoglobulin heavy-chain enhancer.}

R H Scheuermann and U Chen

Genes Dev. 1989, 3:

Access the most recent version at doi:10.1101/gad.3.8.1255

References This article cites 58 articles, 17 of which can be accessed free at: http://genesdev.cshlp.org/content/3/8/1255.full.html\#ref-list-1

License

Email Alerting

Service

Receive free email alerts when new articles cite this article - sign up in the box at the top right corner of the article or click here.

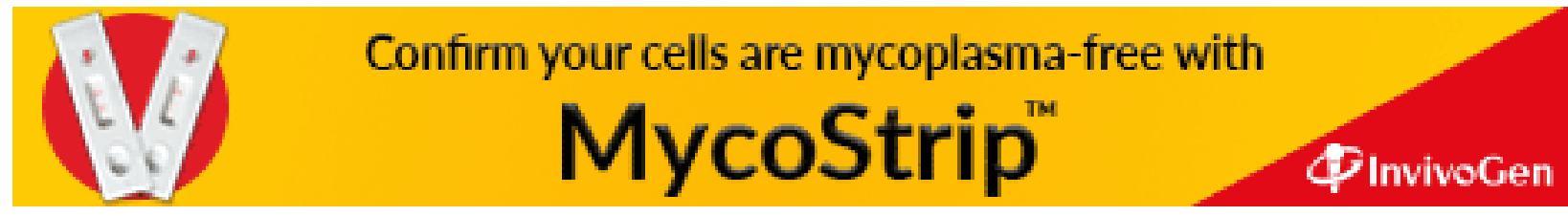

